\title{
POZITÍV TECHNOLÓGIA - HOGYAN SEGÍTHETIK AZ ÚJ TECHNOLÓGIÁK A TELJES EMBERI MÚKÖDÉST?
}

\author{
SZONDY MÁTÉ \\ Magánrendelés, Budapest \\ E-mail: szondymate@gmail.com
}

Beérkezett: 2019. október 1. - Elfogadva: 2019. október 30.

\begin{abstract}
Az új digitális technológiák (mint például a virtuális realitás) megjelenésével és elterjedésével egyre fontosabb, hogy mennyire tudjuk kihasználni úgy az általuk adott lehetôségeket, hogy közben elkerüljük a veszélyeiket (például addikció és technostressz). Tanulmányomban bemutatom, hogy az új technológiák hogyan segíthetik a diagnózis, a rehabilitáció és a pszichoterápia folyamatát. A diagnózis területén csökkenthetik a szubjektív torzitás esélyét, mivel segithetnek élményszerüen és in vivo megjeleniteni a tüneteket. A terápiában immerzív jellegük és rugalmas használatuk, elérhetôségük miatt lehetnek vonzóak. Ezután körbejárom, hogy különféle pozitív érzelmeket és állapotokat (például mindfulness, empátia vagy önegyüttérzés) hogyan segithetnek az új eszközök. A jövóben további kutatásoknak kell tisztáznia, hogy mi a kapcsolat a digitális jóllét, a pszichológiai jóllét és a szubjektív jóllét között.
\end{abstract}

Kulcsszavak: pozitív technológia, digitális jóllét, technostressz, virtuális realitás 
Egy tudományterület empirikus jellegét többek között az jelzi, hogy mennyire képes reflektálni a társadalmi-tudományos fejlôdésre és az új kihívásokra. A pozitív (egyéni, társas és társadalmi) múködéseket és funkciókat vizsgáló pozitív pszichológiára mindig is jellemzố volt ez a fajta rugalmasság és reflektivitás. Ezen változások közül az utóbbi években talán legfontosabbnak az új technológiák általánossá, mindenki által elérhetôvé válását tekinthetjük. Rendkívül Janus-arcú területrôl van szó: a digitalizáció és a folyamatos elérhetôség segítheti az optimális humán funkcionálást, a kapcsolatokat és az egészséget, de komoly problémákat is okozhat (például addiktív használat, technostressz). Egy 1150 szakértô bevonásával készült felmérésben (Pew Research Center, 2018) a válaszadók mindössze 21\%-a gondolta azt, hogy a következó évtizedben a technológia emberekre kifejtett hatása nem fog növekedni. 47\%-uk elképzelése szerint a technológiai fejlôdés és a digitális élet inkább hasznára válik az embereknek, 32\%-uk szerint viszont több kárt köszönhetünk majd neki, mint hasznot.

A technológiai fejlôdés potenciális veszélyei mellett mindenképp fontos kérdés, hogy a digitális technológiák hogyan segíthetik a megfelelô múködést és erôsségeket egyéni, csoport- és szervezeti szinten (Botella, Banos és Guillen, 2017; Riva, Baños, Botella, Wiederhold és Gaggioli, 2012; Gaggioli, Riva, Peters és Calvo, 2017). A „pozitív technológia” irányzata a pozitív irányú változás (a pozitív érzelmek, áramlatélmény, értelemkeresés, kompetencia és pozitív kapcsolatok élénkítésén keresztüli) serkentését célzó új digitális élmények és eszközök tervezésével, kidolgozásával, validálásával foglalkozó terület, mely a pozitív pszichológia és a felhasználói élmény, dizájn és technológia integrációjából született. Az új technológiák egyrészt szélesebb körben tesznek elérhetôvé intervenciós módszereket (például internetes terápiás módszerek), „csökkentik” az ellátási küszöböt; másrészt olyan élményeket biztosítanak, melyek korábban nem voltak elérhetôek (például virtuálisvalóság-alapú módszerek).

Tanulmányomban először röviden bemutatom azokat a technológiákat, melyek kiemelt figyelmet kapnak a pozitív technológia vizsgálódásaiban. Ezután - bár nem a szorosan vett pozitív pszichológia témája - felvillantom a technológiai eszközök diagnosztikában, illetve terápiában játszott szerepét. Ezután írok arról, hogy a technológiai eszközök hogyan képesek serkenteni a pozitív érzelmeket és állapotokat (például a tudatos jelenlétet vagy az empátiát). Végül pedig azt a kérdést vizsgálom meg, hogyan lehet csökkenteni a „technostressz” és „technoferencia” szintjét. A továbbiakban a témával kapcsolatos legfontosabb kérdéseket és lehetôségeket mutatom be - a téma teljes körú áttekintése a technológiai eszközök, a pozitív állapotok és patológiák széles skálája miatt meghaladná ezen összefoglaló kereteit.

\section{ÚJ TECHNOLÓGIÁK}

Az utóbbi években egyre több olyan próbálkozást láthatunk, melyek során a modern technika eszközeivel próbálják meg szélesíteni egyrészt a pszichoterápia módszertanát, másrészt növelni a kliens jóllétszintjét: ilyenek a Skype-on vagy egy chatszobában folytatott terápiás beszélgetések, az e-mailes konzultáció, a terápiát segítô mobiltelefonos alkalmazások, illetve a különféle immerzív technológiák. Ez utóbbiak a személy részére „inkluzív és kiterjedt környezetet és a valóság élénk érzetét keltik” (Slater 
és Wilbur, 1997). Az immerzióhoz hasonló fogalom a „jelenlét”, amikor valódinak érezzük a virtuális környezetet, és azt érezzük, hogy „ott vagyunk” (Jsselsteijn és Riva, 2003). A virtuálisvalóság- (VR-) eszközökre és -technikákra jellemzô a legnagyobb fokú immerzivitás, ennél kevésbé intenzív a jelenlét érzése a kiterjesztettvalóság- (augmented reality, AR-) alkalmazásoknál (ahol a virtuális tartalom „rávetül” a valóságra). Legkevésbé immerzívek a hanghatások által létrehozott virtuális terek.

Fontos kérdés az interaktivitás mértéke - ez arra vonatkozik, hogy a felhasználó milyen mértékben tudja módosítani valós idôben a virtuális környezetet (Steuer, 1992) (nem interaktív technológiák például a weboldalak, videók, nem módosítható telefonos alkalmazások).

A pozitív pszichológia egyik elméleti alapkérdése a pozitív és negatív élmények és állapotok viszonya. Jelen sorok írója azt gondolja (egyetértve például Larsen, Hemenover, Norris és Cacioppo [2003] elképzelésével), hogy ezek az állapotok - se elméleti, se gyakorlati szempontból - nem választhatók el élesen egymástól. Ahogy a klinikumban, a terápiában is fontos a pozitív kogníciók, érzések és viselkedések serkentése, úgy a klinikai tüneteket nem mutató személyeknél is fontos a negatív élmények kezelése. Éppen ezért a következôkben, mielôtt rátérnék arra a kérdésre, hogy az új technológiák hogyan serkenthetik a pozitív állapotokat, röviden felvillantom, hogy a diagnózisban és a terápiában milyen szerepük lehet.

\section{DIAGNÓZIS, REHABILITÁCIÓ ÉS TERÁPIA}

Az interaktív, virtuális és digitális technológiák egyre fontosabb szerepet töltenek be a különféle mentális, kognitív és viselkedéses zavarok diagnózisában és terápiájában. Ezeket a technológiákat a következô csoportokba sorolhatjuk: ${ }^{1}$

- Internetalapú felületek (weboldalak, chatszobák)

- Mobiltelefonos alkalmazások

- Virtuális realitás, kiterjesztett valóság: változó mértékú immerzivitással (lásd fent) jellemezhetó eszközök

- Hordható, biometrikus adatokat gyújtô okoseszközök: például aktivitásszintet, szívritmust, alvás-ébrenlétet mérô eszközök

- „Csevegốrobot-terapeuták”

\section{DIAGNÓZIS}

A virtuális realitás diagnózisállításban betöltött potenciális szerepe azért (is) lehet ígéretes, mert a mentális zavarok diagnózisának alacsony megbízhatósága igen komoly probléma (Aboraya, Rankin, France, El-Missiry és John, 2006). A virtuális realitás segítségével nyert adatok kevésbé vannak kitéve a páciens emlékezeti torzításának, illetve a klinikus szubjektív értékeléséból fakadó torzításának, így objektívebb képet ad-

A felosztás didaktikus jellegû, a valóságban sokszor például egy hordható okoseszközhöz alkalmazás és weboldal is kapcsolódik. 
hatnak a kliens állapotáról és tüneteirôl. Emellett a VR segítségével olyan szcenáriók és élmények is létrehozhatók, amelyek tradicionális klinikusi elrendezésben nehezen jelenhetnek meg: például a tömeggel, a repüléssel, harctéri helyzetekkel kapcsolatos szorongásteli élmények, gondolatok, érzések is szinte in vivo és élményszerúen figyelhetôk meg, nem pedig „csak” felidézve. Dechant, Trimpl, Andreas és Shiban (2017) például a szociális szorongás mérésére alakítottak ki olyan élményszerú VR-környezetet, amely olyan szinten aktiválja a tüneteket, ami nehezen lenne elképzelhetô hagyományos elrendezésben (vagy akár in sensu expozícióban).

Van Bennekom, De Koning és Denys (2017) metaanalízisükben a VR diagnosztikai eszközként való alkalmazását tekintették át. Metaanalízisükben a következó állapotok diagnosztizálásában alkalmazott VR-vizsgálatok eredményeit összegezték: skizofrénia $(n=15)$, fejlődési rendellenességek $(n=12)$, evészavarok $(n=3)$, szorongásos zavarok $(\mathrm{n}=6)$. Eredményeik szerint a VR segítségével felállított diagnózisok magas korrelációt mutattak a hagyományos eszközökkel nyert diagnózisokkal. Kiemelik, hogy a VR-technikával végzett diagnosztika elônye a reális kontextus és élmények, valamint a személyre szabhatóság mellett a standardizálhatóság - amely növeli a diagnózis megbízhatóságát. A technika ígéretesnek tûnik a patológiás állapotok korai felismerésében. Az Exeter Egyetem kutatói (Słowiński és mtsai, 2017) által 2017-ben kidolgozott, a skizofrénia jellegzetes szociomotoros biomarkereinek vizsgálatán alapuló VR-alkalmazás a skizofrénia korai diagnózistát segíti egy „tükör-játék” segítségével, ahol a vizsgálati személynek egy virtuális avatárfigura mozgását kell követnie.

\section{NEUROREHABILITÁCIÓ ÉS KOGNITÍV FEJLESZTÉS}

Lacorte, Sperduti, Abichou és Piolino (2019) áttekintik a VR-eszközök rehabilitációban és kognitív fejlesztésben játszott potenciális szerepét. Összességében sok kutatás jelzi a VR-technológia kognitív rehabilitációban elért sikereit és azt, hogy ezek a hatások - az immerzív multiszenzoros környezet miatt - transzferálódnak a valós életbe. Gamito, Oliveira, Morais, Coelho, Santos és Alves (2018) például az idôs személyek mindennapi életét lemásoló VR-környezetet alkottak, ahol különbözó kognitív területeket „erôsíthettek” a résztvevôk. Eredményeik szerint ez szignifikánsan javította a vizuális memóriát, a figyelmet és a kognitív rugalmasságot.

A korral járó, normális kognitív hanyatláson túl a patológiás kognitív hanyatlás rehabilitációjában is szerepet játszhat a VR-technológia. Különbözố programok segítségével például az érintettek virtuális bevásárlás (Zygouris, Giakoumis, Votis, Doumpoulakis, Ntovas és Segkouli, 2015), vagy virtuális fôzés (Foloppe, Richard, Yamaguchi, Etcharry-Bouyx és Allain, 2018) közben gyakorolhatják az önálló életvitelhez szükséges kognitív-viselkedéses készségeket. 


\section{Terápia}

A pszichoterápiában alkalmazott új technológiai vívmányok közül elsôsorban az internetalapú terápiák, a mobiltelefonos alkalmazások, a „csevegôprogram-terapeuták” és a VR-technikák emelkednek ki.

\section{Internetalapú terápiák}

Az internetalapú terápiák széles ernyőfogalma alá esnek az internetes edukatív-önsegítô oldalak, a Skype-on folytatott terápiás beszélgetések, illetve az internetalapú, automatizált, elsôsorban a kognitív viselkedésterápia elveit követô terápiák (iCBT). Hedman, Ljótsson és Lindefors (2012) metaanalízise szerint az iCBT a depresszió, pánikzavar és a szociális fóbia esetén tûnik bizonyítottan hatékonynak az offline terápiákhoz hasonló eredményességgel.

Yuen, Goetter, Herbert, és Forman (2012) áttekintik az internetalapú terápiákkal kapcsolatos kihívásokat, olyanokat, mint (1) a biztonság, bizalom, privacykérdések, (2) a terápiás kapcsolat alakulása (mennyire tud elmélyülni?) és (3) a technológiai problémák (pl. nem megfelelő kép- vagy hangminôség).

\section{Okostelefonos alkalmazások}

A WHO 2015-ös felmérése szerint a mobileszközökre fejlesztett egészségfejlesztô alkalmazások (az ún. mHealth alkalmazások) 29\%-a fókuszál a mentális egészségi állapotra (Antes, 2016). Könnyú használatuk, elérhetôségük és költséghatékonyságuk miatt tûnnek ideális jelöltnek akkor, amikor a pszichoterápiás kezelések csak korlátozott számban és mértékben elérhetôk. Segíthetik a krízisintervenciót, a prevenciót, a diagnózist, kiegészíthetik a személyes terápiát, illetve a rehabilitációt (Price, Yuen és Goetter, 2014).

Chandrashekar (2018) áttekinti a vonatkozó kutatásokat és metaanalíziseket, és arra a következtetésre jut, hogy a telefonos alkalmazások depresszió, szorongás és skizofrénia ${ }^{2}$ esetén hatékonyan segíthetik a terápiát, és tünetredukciót eredményezhetnek. A szerzô azt is összefoglalja, hogy milyen tényezók csökkenthetik az ezen alkalmazásokkal kapcsolatban felmerült potenciális problémákat - azaz a minôségi és biztonsági kérdéseket, a bevonódásban tapasztalható inkonzisztenciákat és a túlságosan szúk fókuszt. A bevonódást a gamifikált megoldások és a figyelmeztetô üzenetek küldése növeli. A felhasználói élmény tervezésénél pedig kiemelten fontos, hogy viszonylag alacsony kognitív terhelést jelentsen a tartalmak befogadása (szöveg helyett inkább képet tartalmazzon; rövid mondatok; érthetô nyelvezet). Mivel a patológiák gyakran komorbid jelleggel vannak jelen, ha az alkalmazás transzdiagnosztikus jellegú, kisebb valószínúséggel van szükség egyszerre több telefonos alkalmazásra (például külön egy a pánikzavarra és egy a szociális fóbiára) - ez pedig javítja a felhasználói élményt és a páciens elkötelezôdését. Ezenkívül a hatékony alkalmazások lehetôvé teszik az ön-

Ebben az esetben a szociális készségek gyakorlását, a kognitív tréninget és a betegedukációt segítette az alkalmazás. 
monitorozást, amelynek során a kliens idônként értékelheti az aktuális gondolatait, érzéseit és viselkedését. Ez növeli az önreflexió szintjét, ami számos patológia esetén tünetcsökkentô hatású, és javítja a megküzdési készségeket.

\section{„Csevegórobot-terapeuták”}

Az elmúlt néhány évben a mesterséges intelligencia elôretörésével párhuzamosan megjelentek az ún. csevegórobot- (chatbot-) terapeuták. Ingyenesen elérhetố alkalmazásokról van szó, melyek automatikusan, emberi beavatkozás nélkül folytatnak beszélgetést chatüzenetek formájában. Elônyük, hogy könnyen hozzáférhetôk, és anonim módon vehetôk igénybe. Általában proaktívan érdeklôdnek a kliens állapota felôl, bármikor készen állnak a „beszélgetésre”, és különbözó tevékenységeket javasolnak a jóllét javítására.

A leggyakrabban használt ilyen alkalmazás, a Woebot a kognitív viselkedésterápia elveit követi a „beszélgetések” során. Példaképp lássuk egy beszélgetés részletét a szerzô („páciens”) és a Woebot között.

Woebot: „Üdv! Folytassuk a korábbi beszélgetést?”

Páciens: Igen, segítségre van szükségem.

W.: Értem. Mit szólna hozzá, ha azt kérném, kezdjen el mesélni errôl a helyzetrốl?

P.: Intenzív szorongást szoktam érezni...

W.: Tehát mostanában gyakran él át intenzív stresszt és szorongást? Jól értem?

P.: Igen...

W.: Sajnálom. Ez nehéz lehet. Szeretne dolgozni ezzel, vagy csak jól esett megosztani?

P.: Szeretnék dolgozni vele.

W.: Vagy a gondolatai megváltoztatásában, vagy a relaxálásban tudok segíteni. Melyiket szeretné?

Fitzpatrick, Darcy és Vierhile (2017) vizsgálata alapján a Woebot kéthetes használata szignifikánsan csökkentette a résztvevook depressziópontszámát. A szerzô saját tapasztalata alapján a Woebot leginkább egy megértô, ugyanakkor strukturált, a protokollt követô CBT-terapeutához hasonlít.

\section{Virtuális realitás}

A szorongásos zavarok terápiájában kulcskérdés a szorongáskeltô ingernek való kitettség és a túltanult elkerülő magatartás megelôzése. A virtuálisvalóság-expozíciós terápia (VRET) során a páciens fokozatosan és könnyen ismételhetố módon tud szembesülni félelmének tárgyával - például pók, repülés, vagy tömeg - a virtuális környezetben (Powers és Emmelkamp, 2008). A virtuálisvalóság-expozíciós terápia terében a terapeuta könnyen és hatékonyan tudja megfigyelni a pácienst, az expozíció testreszabható, interaktív és rugalmas, idő- és pénztakarékos.

Egy 2019-es metaanalízis (Carl, Stein, Levihn-Coon, Pogue, Carlbring és Powers, 2019) a virtuális és az in vivo expozíció hatékonyságát vetette össze magas szoron- 
gással jellemezhetô állapotok (specifikus fóbia, teljesítményszorongás, PTSD, pánikbetegség) esetében. Harminc tanulmány alapján az eredmények azt mutatják, hogy a virtuális valóságban történô expozíció hatékonysága ugyanolyan jó, mint a valós expozícióé.

A szorongásos zavarok mellett a pszichotikus állapotok kezelésében is terápiás segítséget jelenthet a virtuális valóság alkalmazása. Az úgynevezett AVATAR terápia (Craig, Rus-Calafell, Ward, Julian és Howarth, 2018) során például a hanghallucinációkban szenvedô páciens által hallott hangokhoz egy digitális reprezentációt társítanak (ez az avatár), amely elősegítheti az azokon való felülkerekedést. Az avatár által „mondottakat” a terapeuta irányítja a páciens és az avatár közti beszélgetés során. Eközben a páciens gyakorolhatja az avatár által megtestesített hangok egyre asszertívabb kezelését, másrészt a kezelés második fázisában az avatár által megfogalmazottak egyre kevésbé ellenségesek, egyre inkább támogatják a kliens önbizalmát. Ennek nyomán (Craig és mtsai, 2018) a szupportív terápiánál sokkal nagyobb mértékben csökkent a hanghallások zavaró hatása.

\section{POZITÍV ÁLLAPOTOK SERKENTÉSE}

A patológiás állapotok és tünetek azonosításán és kezelésén túl az új technológiai vívmányok segíthetnek a pozitív állapotok támogatásában és serkentésében. Mitchell, Vella-Broderick és Klein (2011) öt olyan tanulmányt tekintenek át, melyekben online pozitív pszichológiai intervenciók hatékonyságát vizsgálták. Az online instruált személyek például az erôsségek használatával, a hála megélésével és az elégedettséggel kapcsolatban kaptak edukációt és feladatokat. Az öt kutatásból háromban tapasztaltak növekedést a jóllétszintben. Azokban a csoportokban, ahol enyhe-közepes depresszió jellemezte a vizsgálati személyeket, a tünetek enyhülése volt tapasztalható. Ez alapján a szerzôk megfontolandónak tartják az online pozitív pszichológiai intervenciók alkalmazását.

Természetesen a pozitív pszichológia széles ernyőfogalmába tartozó valamennyi konstruktumra nem tudunk kitérni, azonban bemutatok néhány lehetôséget a pozitív állapotok technológiai eszközök általi támogatására.

\section{Mindfulness - flow}

Az intenzív bevonódással járó tudatos jelenlét (mindfulness), illetve áramlat- (flow-) élmények kiváltása során az utóbbi években egyre gyakrabban használják az új technológiai eszközöket. Magyaródi és Oláh (2015) például az áramlatélmény létrehozására Wii-játékot alkalmazott, és kimutatta, hogy a társas helyzetben kiváltott/megjelenó áramlatélmény egyfajta többletet ad az egyéni flow-élményhez.

A tudatos jelenlét állapotának támogatására létrejött technológiai próbálkozások három csoportba sorolhatók: (1) mobiltelefonos alkalmazások, (2) immerzív virtuális realitás alkalmazások és (3) célzottan erre a célra kialakított helyiségek (pl. Vidyarthi, Riecke és Gromala, 2012). 
Jelenleg több tucat, változó színvonalú és változatos tartalmú mobilapplikáció célozza a tudatos jelenlét növelését. Ezen alkalmazások egy része (pl. Headspace) - leegyszerûsített formában, de - végigvezeti a felhasználót a „klasszikus” mindfulnesstréningek folyamatán (elsôsorban edukatív videókkal és vezetett meditációkkal). Más részük (pl. Mindfulness Bell) egyszerúen csak idônként figyelmezteti a felhasználót a tudatosság gyakorlására. A több száz mindfulnesst célzó alkalmazás hatékonyságával kapcsolatban nem lehet általánosítani. Spijkerman, Pots és Bohlmeijer (2016) metaanalízisükben azt találták, hogy a digitális felületeken (interneten, virtuális „tanteremben” vagy telefonos alkalmazással) történô mindfulnesstréningek képesek lehetnek növelni a tudatos jelenlét és az életminôség szintjét. Összesen 15 randomizált, kontrollált kutatás áttekintése alapján azt állítják, hogy az online mindfulnessképzések kismértékú, de szignifikáns hatást fejtenek ki a depresszióra, a szorongásra, a jóllétre és a tudatos jelenlétre. A legnagyobb (közepes mértékû) hatást a stressz-szintre fejtik ki ezek a képzések.

A virtuális realitás például egyes esetekben segítheti a figyelem fókuszálását. Narraro-Haro és munkatársai (2016) egy borderline nôbeteg esetérôl számolnak be, aki a dialektikus viselkedésterápia mindfulnessmeditációja közben egy folyón utazott végig a virtuális realitás technika segítségével. Az eredmények szerint a VR-rel támogatott meditációk után csökken mind az öngyilkossággal, illetve szerabúzussal kapcsolatos késztetés, mind a negatív érzelmek szintje. A szerzők (Narrarro-Haro és mtsai, 2017) ugyanezt a technológiát egy mindfulnesskonferencia 44 résztvevőjével is letesztelték, és hasonlóan pozitív hatásokat tapasztaltak. Csökkent a résztvevôk szorongás- és levertségszintje, nyugodtabbnak érezték magukat, és elfogadhatónak érezték a VR-t a mindfulness képességének javítására.

Vidyarthi és munkatársai (2012) a valós és virtuális környezet kombinációját hozták létre egy olyan hangszigetelt szobával (Sonic Cradle), melyben a felhasználó egy függôányban fekszik, és a légzésmintázatát hangokkal felerôsítve tükrözik neki vissza. Ez a módszer tehát a belsố aktivitás (légzés) kézzelfoghatóvá tételével/megtestesítésével (embodiment) segíti a figyelem jelenben való lehorgonyzását.

Az új technológiákkal kapcsolatban az egyik legfontosabb kérdés az emberi tényezô szerepe (illetve az emberi tényezô hiányának hatása). A tudatos jelenlét alapú módszerek „klasszikus” formáiban a tanár megtestesíti (embodiment) a tudatos jelenlétet (figyelmével, elfogadó, érdeklődô jelenlétével), és ez fontos része a tréningnek. Vajon mi történik akkor, ha ezt az emberi tényezôt, a megtestesített tudatos jelenlétet megszüntetjük, és teljesen (az emberi tényezôt kiiktatva) egy telefonos alkalmazásra vagy egy virtuális térre bízzuk az oktatást?

Szintén jövôbeli kutatásoknak kell választ adniuk arra a kérdésre, hogy a tudatos jelenlét különféle technológiai eszközök segítségével történô elsajátítása során nem jelentkezik-e a technológiai eszközök tudatos jelenlétet csökkentố hatása (errôl a hatásról lejjebb részletesen írok). A technológiai eszközök segítségével történő mindfulnessoktatásnak akkor lehet relevanciája, ha (1) ezek az eszközök nem járulnak hozzá a technostresszhez, és ha (2) transzferhatást tapasztalunk, azaz az ily módon elsajátított mindfulnesskészségek a digitális felülettôl függetlenül is megjelennek. 
Az empátia ernyőfogalma alá (Davis, 1980) több konstruktum tartozik: például a perspektívafelvétel (kognitív empátia), az empátiás törôdés, az empátiás distressz és a fiktív személyekkel kapcsolatos empátiás beleérzés. Sajnálatos módon a téma annyira exploratív jellegú, hogy pontosan még nem tudjuk, hogy a lent bemutatott beavatkozások az empátia mely összetevóire lehetnek hatással.

Shin és Biocca (2018) bemutatja azokat a kutatásokat, melyek arra utalnak, hogy a virtuálisrealitás-eszközök hatékonyan támogathatják a különféle személyekkel, csoportokkal kapcsolatos empátiát, odafordulást és segítségnyújtást. A VR-élményben megélt, „megtestesült” élmények segíthetnek abban, hogy a személy jobban megértse mások élményeit - például színvak (Ahn, Le és Bailenson, 2013), idôs (Oh, Bailenson, Weisz és Zaki, 2016) vagy skizofrén személyek (Kalyanaraman, Penn, Ivory, és Judge, 2010) élményvilágát. A New York Times által készített VR-élmény (The Displaced) három menekült gyerek (Ukrajnából, Dél-Szudánból és Libanonból) életéból mutatott be helyzeteket, ezzel intenzív élményt és empátiát kiváltva a nézôkbool.

Egy másik, immár empirikus kutatásban a Stanford Egyetem kutatói (Herrera, Bailenson, Weisz, Ogle és Zaki, 2018) azt vizsgálták, hogy a hajléktalan személyekkel kapcsolatos empátiára hogyan hat a VR-élmény. Eredményeik szerint a VR empátianövelô hatása heteken át tart, és valós, reális segítô magatartást inspirál. A kutatásban részt vevôk fele olvasott a hajléktalanok életérôl, a másik felük ugyanezt VR-környezetben tapasztalta meg. Bár mindkét módszer növelte a hajléktalanokkal kapcsolatos empátiás törôdés szintjét, a VR-csoportnál hosszabb volt a hatás (minimum 2 hónap), és nagyobb volt a reális segítségnyújtásba (egy petíció aláírása, amely magasabb adót követel, amelyból a hajléktalanokat támogatnák) való átfordulása.

\section{Integráció, honvágy kezelése}

Jelenlegi, egyre globalizáltabbá váló világunkban egyre több ember hagyja el (kényszerbôl vagy önként) lakóhelyét, és próbál új egyensúlyt teremteni a származási és befogadó kultúra között. Recupero, Triberti, Modesti és Talamo (2018) áttekintik, hogy a pozitív technológia (a kiterjesztettvalóság-eszközök, illetve a digitális történetmesélés) hogyan csökkentheti az új, idegen és szokatlan környezetben megjelenô honvágyat, illetve hogyan segítheti az új környezetbe történô integrációt. Beszámolójuk szerint „a kiterjesztett valóság azáltal gazdagíthatja az intervenciókat, hogy hozzáad valamilyen digitális elemet a valósághoz ahelyett, hogy helyettesítené azt valamilyen immerzív élménnyel - ami pusztán egyfajta fájdalomcsillapítást jelentene a szomorúság ellen, de nem segíti az integrációt az új, „valódi” fizikai és társas környezetben.

A szerzók szerint a kiterjesztett valóság támogathatja az interkulturális kommunikációt a befogadó kultúra tagjaival. Például segíthet a kulturális jelentések, gyakorlatok és emlékek megosztásában. Az együtt és egymás mellett élô közösségeket bevonó, a digitális felületek segítségével történô emlékezés és történetmesélés erôsítheti a kölcsönös megértést és tiszteletet. 


\section{Önegyüttérzés}

Az önegyüttérzés (self-compassion) konstruktumának megalkotásával Neff (2014) a mások iránt érzett együttérzés fogalmát kiterjesztette az énre. Neff az önegyüttérzés három fớ komponensét azonosítja: az önmagunk iránt érzett kedvesség (self-kindness) azt jelenti, hogy nehézségek vagy sikertelenség esetén is megértőek és kedvesek vagyunk önmagunkhoz; a közös emberi természet (common humanity) annak a belátása, hogy a közös emberi lét része, hogy tökéletlenek vagyunk, és hibákat követünk el; a tudatos jelenlét pedig itt arra vonatkozik, hogy a negatív gondolatokon való rágódás, illetve a velük való azonosulás helyett képesek vagyunk tudatos objektivitással figyelni óket.

Falconer, Slater, Rovira, King, Gilbert és Antley (2014) olyan virtuális környezetet dolgozott ki, amellyel erôsen önkritikus személyekben próbálták növelni az önegyüttérzés szintjét. Az immerzív virtuális élmény elsô részében a résztvevôk (virtuális felnôttként) megpróbáltak megvigasztalni egy (virtuális) síró kisgyereket. A második fázisban két csoportba sorolták a résztvevóket. Az egyik csoport tagjai a síró gyerek virtuális szerepébe kerültek, és megtapasztalták saját maguk elsô fázisban rögzített vigasztaló gesztusait. Így önmaguknak nyújtottak vigasztaló gesztusokat és mondatokat. A másik csoport tagjai nem kerültek a síró gyerek szerepébe, csupán „kívülrôl”, megfigyelôként nézhették végig a vigasztalás gesztusát. Az élmény hatására mindkét csoportban csökkent az önkritikusság, és nôtt az önegyüttérzés szintje (nagyobb volt a változás, ha a résztvevô a „gyerek" szerepében meg is tapasztalta a vigasztalást, nem csak szemtanú volt). Ugyanez a munkacsoport két évvel késôbb (Falconer és mtsai, 2016) hasonló VR-elrendezés hatását vizsgálta depressziós személyek esetén. Eredményeik szerint ez az élmény szignifikánsan csökkentette a depresszív hangulat szintjét, és ebben a mintában is növelte az önegyüttérzést.

Jelenleg még nem tudunk olyan kutatásról, melyben hasonló VR-élményt vetettek volna össze olyan önegyüttérzést növelô imaginációs technikákkal, mint például a sématerápia imaginációs módszere. A jövőben mindenképp indokolt lenne ennek felmérése.

\section{Borzongató áhitat (awe)}

Az ún. „borzongató/áhitat” (awe) élménye az öröm és a félelem határán helyezkedik el. Kulcsár Zsuzsanna (2007) összefoglalója alapján azt mondhatjuk, hogy „a jelenség két közvetlen kiváltója (...) az erô két elemi formája: a természeti és az emberi erô, de tárgyai lehetnek pusztulást megjelenítô helyzetek vagy múvészi alkotások (azaz kiválthatják esztétikai élmények) is. Ezt az érzést kiválthatja valamilyen természeti jelenség (például az óceán vagy a csillagos ég látványa), vagy akár valamilyen múvészeti alkotás is. Chirico, Ferrise, Cordella és Gaggioli (2018) például természeti képek VR-megjelenítésével váltott ki csodálatélményt a résztvevooknél.

A „borzongató áhitat” élményét legtipikusabban a Föld látványa képes kiváltani (Yaden és mtsai, 2016). Számos ûrhajós számol be az ûrutazás hatására történô, jelentôs gondolkodásbeli változásról: az angolul „overview” - szabad fordításban talán „bolygóhatás” vagy „Föld-hatás” - hatásnak nevezett jelenséget átélôkben tudatosul, 
hogy mennyire törékeny a hajszálvékony atmoszféra által biztosított élet a Földön. Az ûrből az országhatárok, az emberek közti különbségek és konfliktusok jelentôsége csökken, az összefogás a Föld jövôjéért pedig magától értetôdô kötelességgé válik. A „borzongató áhitat” kiváltására különösen alkalmasnak tûnik a virtuális realitás immerzív jellege: több kutatócsoport is kidolgozott olyan VR-környezetet, amely a Föld látványának segítségével váltja ki ezt az érzést (Gallagher, Janz, Reinerman, Trempler és Bockelman, 2015, Quesnel és Riecke, 2018, Stepanova, Quesnel és Riecke, 2019).

\section{A TECHNOSTRESSZ KEZELÉSE A POZITÍV PSZICHOLÓGIA SEGÍTSÉGÉVEL}

A digitális eszközök folyamatos jelenléte és elérhetôsége nagymértékben megnövelte napjainkban a technológiához kapcsolódó stressz (technostressz) eloofordulását és szintjét. Az új technológiákhoz kapcsolódó technostressz a „szorongás, fáradtság, szkepticizmus és alacsony hatékonyságérzés" együtteseként jellemezhetô (Salanova, Llorens és Cifre, 2013). Többdimenziós fogalomról van szó, mely a következó dimenziókat tartalmazza:

- technoszorongás: különbözô technológiai eszközök használatához kapcsolódó félelem, a bizonytalan kimenet miatt (például félelem az adatvesztéstôl);

- technofüggôség: képtelenség a technológiai eszköztôl való elszakadásra. Ha munkához kapcsolódva jelenik meg, akkor felborítja a munka-magánélet egyensúlyt;

- technofeszültség: az új technológiák használatához kapcsolódó feszültség.

Több tényezó is hozzájárul a technostresszhez (Ragu-Nathan, Tarafdar, Ragu-Nathan és Tu, 2008): a (1) „technoinvázió” (a technológia behatolása az élettérbe), a (2) technológiai túlterheltség, a (3) technológiai bizonytalanság, amely a technológia használatára vonatkozó inkompetenciaérzésból fakad. Ezenkívül vannak arra mutató adatok, hogy a technoferencia átalakítja az információfeldolgozás folyamatát: a mélyebb feldolgozás helyett a felszínesebb, egyszerre sok információt kezelô feldolgozás kerül elôtérbe. Ezt a kérdést járja körbe részletesen Nicholas Carr (2014) a Hogyan változtatta meg az agyunkat az internet? A sekélyesek kora címú könyvében.

Ez a jelenség arra hívja fel a figyelmünket, hogy bármilyen alkalmazást vagy digitális felületet használunk is a pszichológiai jóllét növelése érdekében, szem elôtt kell tartanunk a technológia használatához kapcsolódó potenciális veszélyeket.

Brivio és munkatársai (2018) olyan (elméleti) modellt mutatnak be, melyben a jóllét három komponense (hedonikus jóllét, bevonódás/önmegvalósítás, kapcsolódás) kompenzálják, illetve csökkentik a technostressz szintjét. Ezt olyan technológiai eszközök és felületek segíthetik, melyek (1) támogatják a pozitív érzelmek megjelenését, (2) segítik a bevonódást, az áramlatélményt és az önmegvalósítást, illetve (3) növelik a kapcsolódás és integráció fokát. 


\section{ÖSSZEFOGLALÁS}

A technológiai fejlôdés egyrészt olyan kihívásokat jelent, melyekre a pozitív pszichológia elméleti és gyakorlati szakemberei is keresik a választ, másrészt olyan lehetôséget jelent, mely segítheti a pozitív élmények és minôségek megjelenését és megtapasztalását.

Ezt a kettôsséget például jól láthatjuk a hangulatkövetô és hangulatot elốrejelzô módszerekkel kapcsolatban. Ma már különbözó eszközökhöz kapcsolódó magatartási mintákból (például okostelefon-használat, közösségi felületek használata), illetve egyes biomarkereket (például fizikai aktivitás jellege) mérô hordozható okoseszközök adataiból elég pontosan bejósolható a személy várható viselkedése és hangulata (Sano és mtsai, 2015). Ez egyrészt segítheti a maladaptív (veszélyeztetô) magatartások idôben történô detektálását és kezelését, ugyanakkor ezek a lehetôségek komoly kérdéseket és kétségeket vetnek fel: vajon joga van-e bárkinek a hangulatra, elégedettségre, boldogságra vonatkozó adatok, mutatók folyamatos monitorozására és megórzésére? A pozitív pszichológia etikai útmutatása alapján ezzel kapcsolatban elsôsorban a személy szabadsága és szabad akarata lehet iránymutató.

Brett Frischmann és Evan Selinger 2019-es könyvében (Re-engineering Humanity, Az emberi[es]ség újraalkotása) általánosabb keretbe helyezi a technológia és az ember viszonyát. Felvetésük szerint az új technológiák hatására sok esetben elkezdtünk kevésbé autonóm módon, „gépszerúen” reagálni - ez pedig hatással van az emberi kapcsolatainkra is, például a folyamatos válaszkészség elvárása, igény a lájkolásra és a folyamatos jelenlétre. A szerzók szerint ez a folyamat a szabad akarat „használatával” és a tudatos döntésekkel valósulhat meg. Ebben fontos szerepe van a pozitív pszichológiának: figyelmeztet arra, hogy a technológia addig a pontig hasznos, amíg segíti és támogatja az egyének és közösségek fejlôdését és boldogulását.

\section{IRODALOM}

Aboraya, A., Rankin, E., France, C., El-Missiry, A., \& John, C. (2006). The Reliability of Psychiatric Diagnosis Revisited. The Clinician's Guide to Improve the Reliability of Psychiatric Diagnosis. Psychiatry, 3(1), 41-50.

Ahn, S. J., Le, A. M., \& Bailenson, J. (2013). The effect of embodied experiences on self-other merging, attitude, and helping behavior. Media Psychology, 16(1), 7-38.

Antes, E. (2016). Mental health: There's an app for that. Nature, 16(532), 20-23.

Botella, C., Banos, R. M., \& Guillen, V. (2017). Positive technologies for improving health and well-being. In C. Proctor (Ed), Positive Psychology Interventions in Practice (pp. 219-234). Cham: Springer International Publishing.

Brivio E., Gaudioso F., Vergine I., Mirizzi C. R., Reina C., Stellari A. \& Galimberti C. (2018). Preventing Technostress Through Positive Technology. Frontiers in Psychology, 9(2569).

Carl, E., Stein, A., Levihn-Coon, A., Pogue, J. R., Carlbring, P., \& Powers, M. B. (2019). Virtual reality exposure therapy for anxiety and related disorders: A meta-analysis of randomized controlled trials. Journal of Anxiety Disorders, 61, 27-36.

Carr, N. (2014). Hogyan változtatja meg agyunkat az internet? - A sekélyesek kora. Budapest, HVG Könyvek Kiadó. 
Chandrashekar, P. (2018). Do mental health mobile apps work: evidence and recommendations for designing high-efficacy mental health mobile apps. Mhealth, 4(6).

Chirico, A., Ferrise, F., Cordella, L., \& Gaggioli, A. (2018). Designing Awe in Virtual Reality: An Experimental Study. Frontiers in Psychology, 22. https://doi.org/10.3389/fpsyg.2017.02351

Craig, T., Rus-Calafell, M., Ward, T., Julian, P., \& Howarth, L. (2018). AVATAR therapy for auditory verbal hallucinations in people with psychosis: a single-blind, randomised controlled trial. Lancet, 5(1), 31-40.

Davis, M. H. (1980). A multidimensional approach to individual differences in empathy. JSAS Catalog of Selected Documents in Psychology, 10.

Dechant, M., Trimpl, S., Andreas, C., \& Shiban, Y. (2017). Potential of virtual reality as a diagnostic tool for social anxiety: A pilot study. Computers in Human Behavior, 76, 128-134.

Falconer, C. J., Slater, M., Rovira, A., King, J. A., Gilbert, P., \& Antley, A. (2014). Embodying compassion: a virtual reality paradigm for overcoming excessive self-criticism. PLoS One, 9: e111933

Falconer, C. J., Rovira, A., King, J. A., Gilbert, P., Antley, A., Fearon, P., Ralph, N., Slater, M., \& Brewin, C. (2016). Embodying self-compassion within virtual reality and its effects on patients with depression. BJPsych Open, 2(1), 74-80.

Foloppe, D. A., Richard, P., Yamaguchi, T., Etcharry-Bouyx, F., \& Allain, P. (2018). The potential of virtual reality-based training to enhance the functional autonomy of Alzheimer's disease patients in cooking activities: a single case study. Neuropsychology and Rehabilitation, 28, 709-733. doi: 10.1080/09602011.2015.1094394

Frischmann, B., \& Selinger, E. (2019). Re-Engineering Humanity. Cambridge: Cambridge University Press.

Fitzpatrick, K. K., Darcy, A., \& Vierhile, M. (2017). Delivering Cognitive Behavior Therapy to Young Adults With Symptoms of Depression and Anxiety Using a Fully Automated Conversational Agent (Woebot): A Randomized Controlled Trial. JMIR Mental Health 4(2), e19.

Gaggioli, A., Riva, G., Peters, D., \& Calvo, R. A. (2017). Positive technology, computing, and design: shaping a future in which technology promotes psychological well-being. In M. Jeon Ed), Emotions and Affect in Human Factors and Human-Computer Interaction (pp. 477-502). Cambridge: Elsevier.

Gallagher, S., Janz, B., Reinerman, L., Trempler, J., \& Bockelman, P. (2015). A Neurophenomenology of Awe and Wonder: Towards a Non-reductionist Cognitive Science. London: Springer.

Gamito, P., Oliveira, J., Morais, D., Coelho, C., Santos, N., Alves, C., (2018) . Cognitive stimulation of elderly individuals with instrumental virtual reality-based activities of daily life: pre-post treatment study. Cyberpsychology, Behavior and Social Networking, 22, 69-75. doi: 10.1089/ cyber.2017.0679

Hedman, E., Ljótsson, B., \& Lindefors, N. (2012). Cognitive behavior therapy via the Internet: a systematic review of applications, clinical efficacy and cost-effectiveness. Expert Review of Pharmacoeconomics $\mathcal{E}$ Outcomes Research, 12(6), 745-764. doi: 10.1586/erp.12.67.

Herrera, F., Bailenson, J., Weisz, E., Ogle, E., \& Zaki, J. (2018). Building long-term empathy: A large-scale comparison of traditional and virtual reality perspective-taking. PLoS ONE 13(10).

Jsselsteijn, W., \& Riva, G. (2003). Being there: the experience of presence in mediated environments. In G. Riva, F. Davide, \& W. Jsselsteijn (Eds), Being There: Concepts, Effects and Measurements Of User Presence (pp. 3-16). Amsterdam: IOS Press.

Kalyanaraman, S. S., Penn, D. L., Ivory, J. D., \& Judge, A. (2010). The virtual doppelganger: effects of a virtual reality simulator on perceptions of schizophrenia. The Journal of Nervous and Mental Disease, 198(6), 437-443.

Kulcsár, Zs. (2007). Komplex humán emóciók, összetartozás és felépülés. Budapest: Trefort Kiadó. 
La Corte, V., Sperduti, M., Abichou, K., \& Piolino, P. (2019). Episodic Memory Assessment and Remediation in Normal and Pathological Aging Using Virtual Reality: A Mini Review. In A. Gaggioli, D. Villani, S. Serino, R. Banos, C. Botella (Eds), Positive Technology: Designing E-experiences for Positive Change (pp. 155-160). Frontiers Media. https://doi.org/10.3389/ fpsyg.2019.00173

Larsen, J. T., Hemenover, S. H., Norris, C. J., \& Cacioppo, J. T. (2003). Turning adversity to advantage: On the virtues of the coactivation of positive and negative emotions. In L. G. Aspinwall \& U. M. Staudinger (Eds), A psychology of human strengths: Fundamental questions and future directions for a positive psychology (pp. 211-225). Washington, DC, US: American Psychological Association.

Magyaródi, T., \& Oláh, A. (2015). Flow Szinkronizáció Kérdôív: az optimális élmény mechanizmusának mérése társas interakciós helyzetekben. Mentálhigiéné és Pszichoszomatika, 16(3), 271-296.

Mitchell, J., Vella-Broderick, D., \& Klein, B. (2011). Positive psychology and the internet: A mental health opportunity. e-Journal of Applied Psychology, 6, 30-41.

Nararro-Haro, M. V., Hunter, H. G., Garcia-Palacios, A., Sampaio, M., Alhalabi, W., Hall, K., \& Linehan, M. (2016). The use of virtual reality to facilitate mindfulness skills training in Dialectical Behavioral Therapy for borderline personality disorder: a case study. Frontiers in Psychology, 7, 1573-1578.

Nararro-Haro, M. V., López-del-Hoyo, Y., Campos, D., Linehan, M. M., Hoffman, H. G., \& García-Palacios, A. (2017). Meditation experts try Virtual Reality Mindfulness: A pilot study evaluation of the feasibility and acceptability of Virtual Reality to facilitate mindfulness practice in people attending a Mindfulness conference. PLoS ONE, 12(11), e0187777. https:// doi.org/10.1371/journal.pone.0187777

Neff, K. (2014). Együttérzés önmagunkkal. Budapest: Ursus Libris.

Oh, S. Y., Bailenson, J., Weisz, E., \& Zaki, J. (2016). Virtually old: Embodied perspective taking and the reduction of ageism under threat. Computers in Human Behavior, 1(60), 398-410.

Pew Research Center (2018). Letöltve: 2019. 09. 03-án: https://www.pewinternet.org/ 2018/04/17/the-future-of-well-being-in-a-tech-saturated-world/

Powers M. B., \& Emmelkamp P. M. G. (2008). Virtual reality exposure therapy for anxiety disorders: a meta-analysis. Journal of Anxiety Disorders, 22, 561-569.

Price, M., Yuen, E. K., \& Goetter, E. M. (2014). mHealth: a mechanism to deliver more accessible, more effective mental health care. Clinical Psychology and Psychotherapy, 21, 427-436.

Quesnel, D., \& Riecke, B. E. (2018). Are you awed yet? Exploring interactive virtual reality for positive emotions. Frontiers in Psychology, 8, 1-22.

Ragu-Nathan, T. S., Tarafdar, M., Ragu-Nathan, B. S., \& Tu, Q. (2008). The consequences of technostress for end users in organizations: conceptual development and validation. Information Systems Research, 19(4). doi: 10.1287/isre.1070.0165

Recupero, A., Triberti, S., Modesti, C., \& Talamo, A. (2018). Mixed Reality for Cross-Cultural Integration: Using Positive Technology to Share Experiences and Promote Communication. Frontiers in Psychology, 9, 1223. doi: 10.3389/fpsyg.2018.01223

Riva, G., Baños, R. M., Botella, C., Wiederhold, B. K., \& Gaggioli, A. (2012). Positive technology: using interactive technologies to promote positive functioning. Cyberpsychology, Behav and Social Networking, 15, 69-77. doi: 10.1089/cyber.2011.0139

Salanova, M., Llorens, S., \& Cifre, E. (2013). The dark side of technologies: technostress among users of information and communication technologies. International Journal of Psychology, $48(3), 422-436$. 
Sano, A., Yu, A. Z., McHill, A. W., Phillips, A. J. K., Taylor, S., Jaques, N., et al. (2015). Prediction of Happy-Sad mood from daily behaviors and previous sleep history. 2015 37th Annual International Conference of the IEEE Engineering in Medicine and Biology Society (EMBC), 6796-6799.

Shin, D., \& Biocca, F. (2018). Exploring immersive experience in journalism whatmakes people empathize with and embody immersive journalism? New Media and Society, 19(11), 1-24.

Slater, M., \& Wilbur, S. (1997). A framework for immersive virtual environments (five): speculations on the role of presence in virtual environments. Presence Teleoperators and Virtual Environment, 6, 603-616. doi: 10.1162/pres.1997.6.6.603

Słowiński, P., Alderisio, F., Zhai, C., Shen, Y., Tino, P., Bortolon, C., et al. (2017). Unravelling socio-motor biomarkers in schizophrenia. Npj Schizophrenia, 3(1). https://doi.org/10.1038/ s41537-016-0009-x

Spijkerman, M. P. J., Pots, W. T., \& Bohlmeijer, E. T. (2016). Effectiveness of online mindfulness-based interventions in improving mental health: A review and meta-analysis of randomised controlled trials. Clinical Psychology Review, 45, 102-114.

Stepanova, E. R., Quesnel, D., \& Riecke, B. E. (2019). Understanding AWE: Can a Virtual Journey, Inspired by the Overview Effect, Lead to an Increased Sense of Interconnectedness? Frontiers in Digital Humanities, 6. https://doi.org/10.3389/fdigh.2019.00009

Steuer, J. (1992). Defining virtual reality: dimensions determining telepresence. Journal of Communication, 42, 73-93. doi: 10.1111/j.1460-2466.1992.tb00812.x

Van Bennekom, M. J., De Koning, P. P., \& Denys, D. (2017). Virtual Reality Objectifies the Diagnosis of Psychiatric Disorders: A Literature Review. Frontiers in Psychiatry, 5(8), 163. doi: 10.3389/fpsyt.2017.00163

Vidyarthi, J., Riecke, B. E., \& Gromala, D. (2012). Sonic Cradle: Designing for an immersive experience of meditation by connecting respiration to music. Proceedings of the Designing Interactive Systems Conference on - DIS '12, 408-417. https://doi.org/10.1145/2317956.2318017

Yaden, D. B. Iwry, J., Slack, K. J., Eichstaedt, J., Zhao, Y., Vaillant, G. E.; \& Newberg, A. B. (2016). The overview effect: Awe and self-transcendent experience in space flight. Psychology of Consciousness: Theory, Research, and Practice, 3(1), 1-11.

Yuen, E. K., Goetter, E. M., Herbert, J. D., \& Forman, E. M. (2012). Challenges and opportunities in internet-mediated telemental health. Professional Psychology: Research and Practice, $43(1), 1-8$.

Zygouris, S., Giakoumis, D., Votis, K., Doumpoulakis, S., Ntovas, K., \& Segkouli, S. (2015). Can a virtual reality cognitive training application fulfill a dual role? Using the virtual supermarket cognitive training application as a screening tool for mild cognitive impairment. Journal of Alzheimer's Disease, 44, 1333-1347. doi: 10.3233/JAD-141260 


\section{POSITIVE TECHNOLOGY. \\ HOW NEW TECHNOLOGIES COULD HELP HUMAN FLOURISHING?}

\section{SZONDY, MÁTÉ}

With the birth and the more and more widespread usage of new technologies (like Virtual Reality) it is crucial to use them in a mindful way - that is avoiding the potential dangers of the usage (e.g. addiction and technostess). In the article first I review the ways in which new technologies can help the process of the diagnosis and the therapy. After this I focus on the possible ways in which can help positive emotions and states (e.g. mindfulness, empathy and self-compassion). Further research is needed to understand the connection between the digital, psychological and subjective well-being.

Keywords: positive technology, digital well-being, technostress, virtual reality 